\title{
THE EFFECT OF ACTH, RENIN, ANGIOTENSIN II, AND VARIOUS PRECURSORS ON BIOSYNTHESIS OF ALDOSTERONE BY ADRENAL SLICES
}

\author{
By NORMAN M. KAPLAN * AND FREDERIC C. BARTTER
}

(From the Clinical Endocrinology Branch, National Heart Institute, National Institutes of Health, Bethesda, Md.)

(Submitted for publication August 15, 1961 ; accepted December 14, 1961)

Angiotensin II has been shown to increase the excretion (1) and secretion (2) of aldosterone by normal human subjects, and the secretion of aldosterone by hypophysectomized, nephrectomized dogs (3-5). In the latter preparation (3), renin, which leads to the liberation of angiotensin in the circulation (6), has been shown to stimulate aldosterone secretion. The present studies were done to determine whether angiotensin and renin can act directly on the adrenal cortex. It will be shown that angiotensin II, like ACTH, does have such a direct effect, and renin does not. The effect of various precursors on the biosynthesis of aldosterone was determined and compared with their effect in the presence of ACTH and angiotensin II. In this way, we have sought to identify and compare the loci of action of ACTH and angiotensin II in the biosynthesis of aldosterone.

\section{METHODS AND MATERIALS}

Tissue preparation and incubation

Beef adrenal slices. Adrenal glands were removed within 15 minutes after slaughter, freed of most of the adhering tissues, and placed in chilled Krebs-Ringer bicarbonate medium. Glands were from cows, except in a few instances when only steers were available. Small pieces of the glands were cut with a Stadie-Riggs microtome adjusted to prepare slices about $0.2 \mathrm{~mm}$ thick. The first (outer) slice was considered to be glomerulosa, the next two to be fasciculata. Separation of the two zones was not complete, however, as shown both by histology and by measurements of steroids. There appeared to be very little of the zona fasciculata in the outer slices, since the amount of cortisol in homogenates of unincubated outer slices was only one-tenth that in the inner slices. The concentrations of aldosterone were approximately equal in the two tissues due to the inclusion

* This investigation was carried out during tenure of a Postdoctoral Fellowship from the National Institute of Arthritis and Metabolic Diseases. Present address: Department of Internal Medicine, The University of Texas Southwestern Medical School, Dallas, Tex. both of a considerable amount of zona glomerulosa in the inner slices and of functionally inactive fibrous capsule in the outer slice.

The slices were minced with scissors and weighed. Specimens weighing about $500 \mathrm{mg}$ were placed in $5 \mathrm{ml}$ of Krebs-Ringer bicarbonate medium containing glucose in a concentration of $200 \mathrm{mg}$ per $100 \mathrm{ml}$. At least 4 vessels were incubated and analyzed separately for each portion of each experiment. Thus, there were at least 4 control vessels and at least 4 with each precursor or stimulating agent studied in each experiment. The tissues were kept chilled until incubation, which was started between 3 and 5 hours after the death of the cattle. Tissues were preincubated for 1 hour at $37^{\circ} \mathrm{C}$ under 5 per cent $\mathrm{CO}_{2}-95$ per cent $\mathrm{O}_{2}$ on the Dubnoff metabolic shaker. The preincubation medium was removed, and $5 \mathrm{ml}$ of fresh medium was used to transfer the slices to vessels to which the appropriate precursor had been added with or without $\mathrm{ACTH}$, renin, or angiotensin II. Incubation was for 2 hours.

The control values for synthesis of aldosterone by the adrenals in vitro showed wide variations from experiment to experiment. The higher the control value, the less was the effect of any given stimulus. Thus, when production of aldosterone by the control beef slices was greater than $2 \mu \mathrm{g}$ per $\mathrm{g}$ of tissue per hour, experimental procedures produced little or no increase of synthesis. Therefore, only preparations with control values below $2 \mu \mathrm{g}$ per $\mathrm{g}$ per hour are included. Factors which may have affected the control level of aldosterone production were water and salt deprivation. Control values were above $4 \mu \mathrm{g}$ per $\mathrm{g}$ per hour only during the winter months when the ground was frozen and the cattle had no access to water for at least 24 to 48 hours before slaughter and limited access to water and salt for a longer period. A stimulatory effect of water deprivation on synthesis of aldosterone in vivo (7) and of salt depletion on synthesis in vitro (8) has been observed. Other factors may have led to this seasonal variation, a problem noted by others studying corticosteroid synthesis in vitro (9). The capacity of the tissue to respond to any given stimulus was found to decrease with the passage of time, so this was kept relatively constant in all experiments.

Rat adrenal sections. The technique of Saffran and Schally (10) was closely followed. A quarter of one adrenal gland from each of eight 150 - to $200-\mathrm{g}$ SpragueDawley male rats was included in each of four vessels 


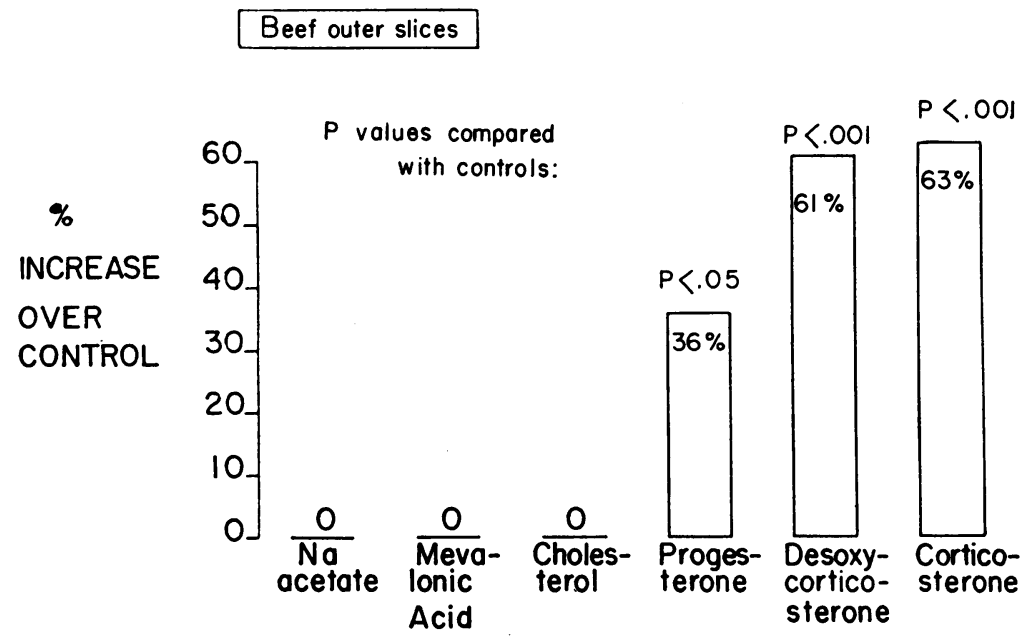

\section{Precursor: all at $20 \mu \mathrm{g} / \mathrm{gram}$ tissue}

Fig. 1. EFfect of NONRAdioactive pReCURSORS ON PRODUCtion OF ALdoSTERONE BY OUTER SLICES OF BEEF ADRENAL CORTEX. In this and in subsequent figures precursors are arranged from left to right in order of their appearance in accepted biosynthetic pathways for aldosterone. These results are for a single experiment in which at least 4 vessels were incubated with each precursor.

for each assay point. The wet weight of tissue in each vessel averaged $30 \mathrm{mg}$. The conditions for preincubation and incubation were the same as those used with the beef adrenal slices with the exception that only $2 \mathrm{ml}$ of medium was added.

In preliminary studies, adrenals from rats anesthetized with pentobarbital were found to show high control values and to be less sensitive to stimulation, as recently reported (11). Accordingly, the animals were simply decapitated. Preincubation was begun within 30 minutes after decapitation of the rats.

\section{Stimulatory agents}

A single batch of porcine ACTH-gel (National), shown to be biologically effective on steroidogenesis in man, was used. Angiotensin II, hereinafter referred to simply as angiotensin, was synthetic asparaginyl-1, valine-5 angiotensin II (Ciba). ${ }^{1}$ It was dissolved in saline just prior to use. Renin was a crude extract of beef kidney prepared by Dr. W. Kleinberg after the method of Haas and Goldblatt (12). This batch was shown to raise blood pressure and stimulate aldosterone secretion in hypophysectomized, nephrectomized dogs at a dosage of $0.2 \mathrm{mg}$ per minute (3). The ACTH, angiotensin, or renin was added to the vessels, and incubation was carried on for 2 hours under the same conditions.

\section{Steroid determinations}

In all experiments with rat sections and in the later ones with beef slices, only the media were analyzed.

\footnotetext{
${ }^{1}$ Kindly supplied by Dr. Robert Gaunt, Ciba \& Co.
}

Assays of homogenates of beef slices from earlier experiments showed that the amount of aldosterone remaining within the tissue varied little from experiment to experiment, and comprised 20 to 30 per cent of the total.

Aldosterone, corticosterone, and cortisol were measured by the double isotope derivative assay of Kliman and Peterson (13). Just before the medium was removed, known amounts of the appropriate $\mathrm{C}^{14}$-ring-labeled steroid were added to each vessel as tracers. Thus, losses during transfer, extraction, and every subsequent step of the determination could be measured. Since recovery of $\mathrm{C}^{14}$-labeled aldosterone varied between 5 and 30 per cent among the vessels of the same experiment, the need for such an internal standard is evident.

All values were expressed as micrograms of steroid per gram of beef tissue or per $100 \mathrm{mg}$ of rat tissue per hour of incubation. In all experiments, the mean of the steroid values in vessels containing precursor or stimulant was compared to that of control specimens simultaneously incubated. When the results of multiple experiments are compared, the values are expressed as the percentage of change from the control specimens. Statistical evaluation was by the $t$ test (14).

\section{RESULTS}

\section{Effect of precursor alone}

Beef adrenal slices (Figure 1 and Table I). The outer slices were incubated with the following precursors: sodium acetate, 20 to $300 \mu \mathrm{g}$ per $\mathrm{g}$ of tissue $\left(5 \times 10^{-5}\right.$ to $\left.7 \times 10^{-4} \mathrm{M}\right)$; sodium meva- 
lonate, 20 to $100 \mu \mathrm{g}$ per $\mathrm{g}$ of tissue $\left(2 \times 10^{-5}\right.$ to $\left.10^{-4} \mathrm{M}\right)$; cholesterol, 20 to $300 \mu \mathrm{g}$ per $\mathrm{g}$ of tissue $\left(10^{-5}\right.$ to $\left.2 \times 10^{-4} \mathrm{M}\right)$; progesterone, deoxycorticosterone (DOC), and corticosterone, all at $20 \mu \mathrm{g}$ per $g$ of tissue $\left(10^{-5} \mathrm{M}\right)$. In one experiment, DOC was added in concentrations ranging from 5 to 100 $\mu \mathrm{g}$ per $\mathrm{g}$ of tissue $\left(3 \times 10^{-6}\right.$ to $\left.6 \times 10^{-5} \mathrm{M}\right)$. There was no increase in aldosterone production with acetate, mevalonate, or cholesterol at any of the concentrations used (Figure 1). Progesterone increased synthesis of aldosterone by 36 per cent, whereas both $\mathrm{DOC}$ and corticosterone had an even greater effect in the experiment in which all precursors were compared (Table I). In the experiment in which increasing concentrations of DOC were added (not shown), production of aldosterone reached a maximum of $3.74 \mu \mathrm{g}$ per $\mathrm{g}$ per hour with $20 \mu \mathrm{g}$ of DOC per g of tissue. At concentrations as high as $100 \mu \mathrm{g}$ per $\mathrm{g}$, DOC caused no further increase in aldosterone synthesis.

Rat adrenal sections (Figure 2). Rat sections were incubated with the following precursors: sodium mevalonate, $20 \mu \mathrm{g}$ per $100 \mathrm{mg}$ of tissue $\left(6 \times 10^{-5} \mathrm{M}\right)$; and cholesterol, progesterone, and DOC, all at $20 \mu \mathrm{g}$ per $100 \mathrm{mg}$ of tissue $(3 \times$ $\left.10^{-5} \mathrm{M}\right)$. The effect of the various precursors on production of aldosterone closely paralleled that found with beef slices (Figure 2). Synthesis of corticosterone was stimulated by progesterone and
TABLE I

Effect of various precursors on aldosterone synthesis by beef adrenal slices

\begin{tabular}{lccc}
\hline \multicolumn{1}{c}{ Precursor } & $\begin{array}{c}\text { No. of } \\
\text { vessels }\end{array}$ & Mean & SD \\
\hline None & & \multicolumn{2}{c}{$\mu \mathrm{g} / \mathrm{g}$ tissue $/ \mathrm{hr}$} \\
Acetate & 5 & 1.62 & 0.13 \\
Mevalonate & 4 & 1.54 & 0.24 \\
Cholesterol & 4 & 1.70 & 0.24 \\
Progesterone & 4 & 1.60 & 0.11 \\
DOC & 4 & 2.20 & 0.42 \\
Corticosterone & 5 & 2.60 & 0.34 \\
& 5 & 2.64 & 0.20 \\
\hline
\end{tabular}

DOC to a much greater degree, and the maximal response may not have been reached.

\section{Effect of $A C T H$, renin, and angiotensin alone}

Beef adrenal slices (Figure 3). ACTH (8 U per $\mathrm{g}$ of tissue), renin (1 $\mathrm{mg}$ per $\mathrm{g}$ of tissue), and angiotensin ( $40 \mu \mathrm{g}$ per $\mathrm{g}$ of tissue) were added without exogenous precursor to outer slices, loosely referred to as "glomerulosa" (see above), and inner slices, loosely referred to as "fasciculata" (see above). The results shown are for a single experiment. Similar results were noted in a second study. Both ACTH and angiotensin significantly increased synthesis of corticosterone and cortisol in fasciculata and of corticosterone and aldosterone in glomerulosa. Although angiotensin had a greater effect on the synthesis of aldosterone

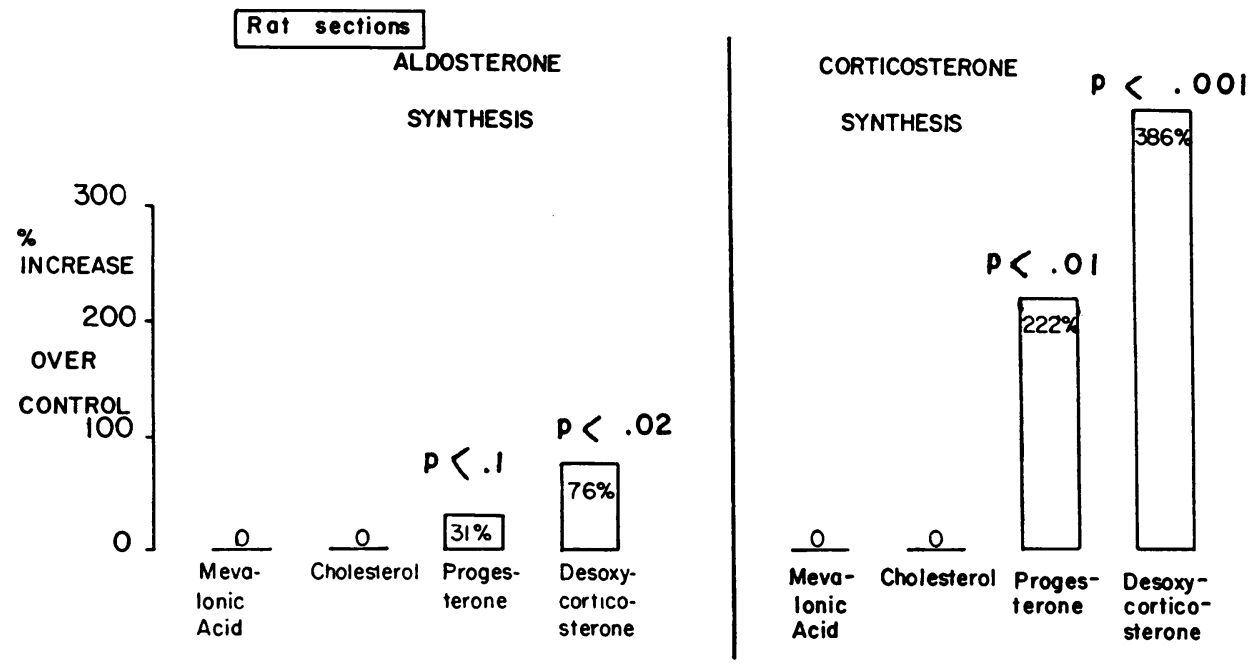

Fig. 2. EFFECT OF NONRADIOACTIVE PRECURSORS ON PRODUCTION OF ALDOSTERONE AND CORTICOSTERONE BY RAT ADRENAL SECTIONS. Each bar represents the average of 2 experiments, in each of which 4 vessels were incubated alone and 4 with the precursor. 

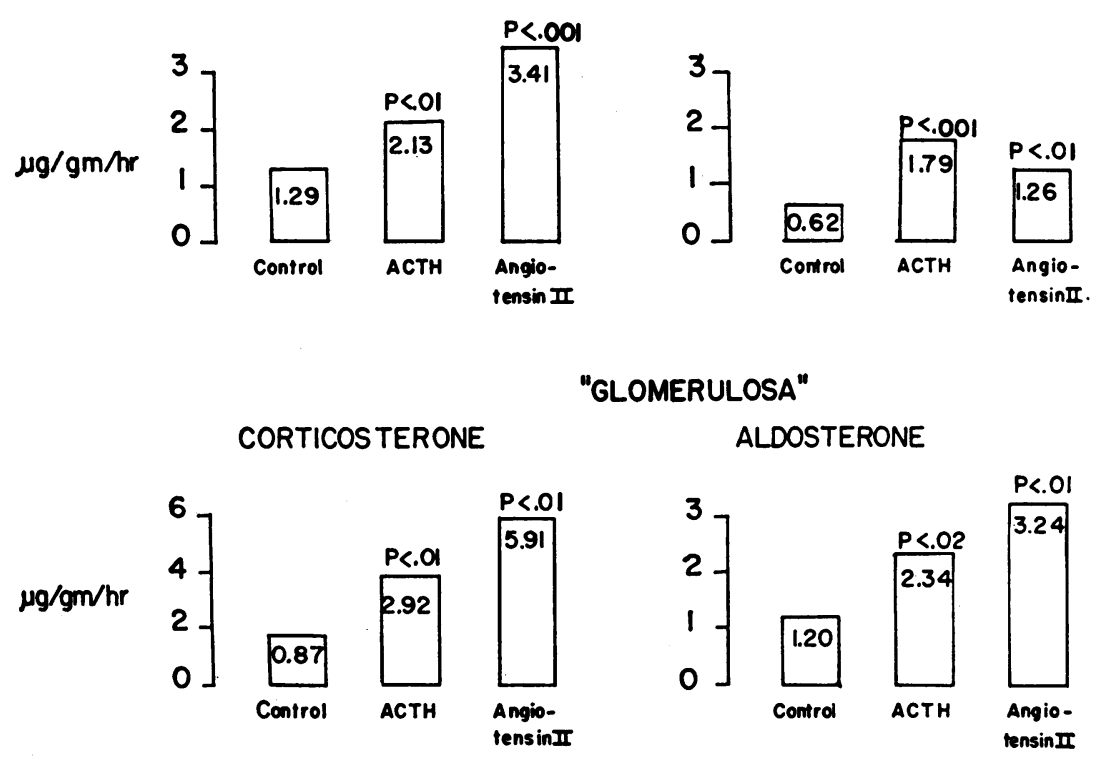

Fig. 3. EFFECT OF ACTH AND ANGIOTENSIN II WITHOUT ADDED PRECURSORS ON THE PRODUCTION OF CORTICOSTERONE AND CORTISOL BY INNER SLICES ("FASCICULATA") AND OF CORTICOSTERONE AND ALDOSTERONE BY OUTER SLICES ("GLOMERULOSA") OF BEEF ADRENAL CORTEX. These values were obtained during a single experiment. Each bar represents the mean value of steroid synthesized in 4 vessels.

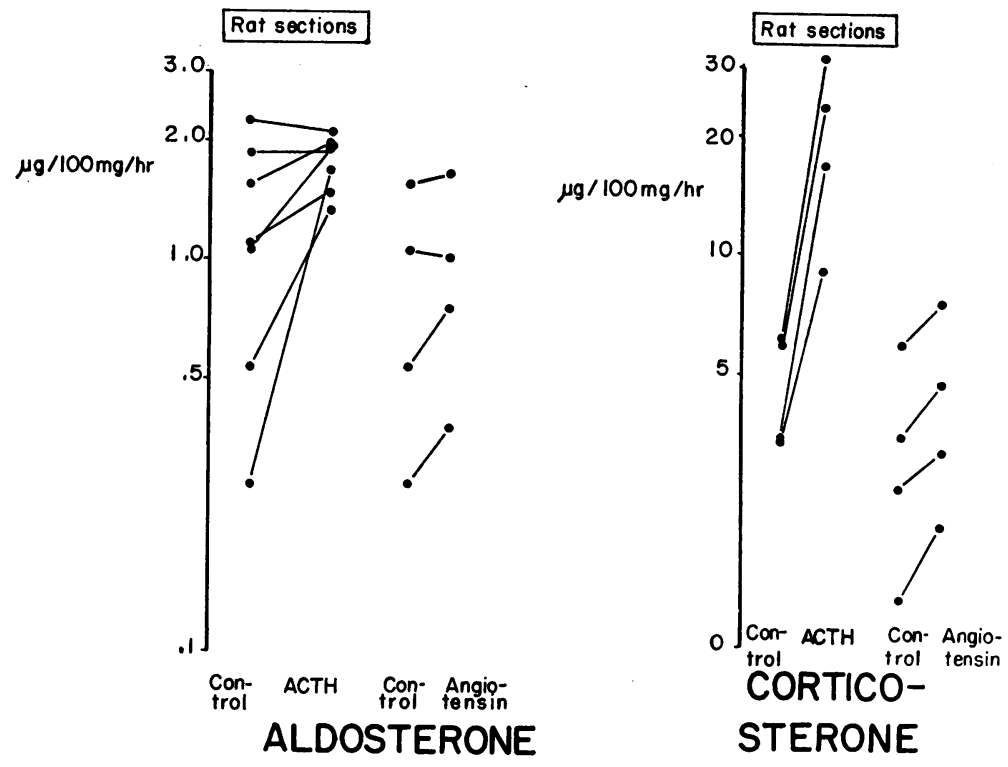

Fig. 4. EfFects of ACTH AND ANGIotensin in Without AdDED PRECURSORS ON THE PRODUCTION OF ALDOSTERONE AND CORTICOSTERONE BY RAT ADRENAL SECTIONS. Each point represents the average of 4 separate vessels in a single experiment. The vessels of each paired point were incubated simultaneously. 
than it had on that of cortisol, while the reverse was true for ACTH, such a comparison has little meaning, since the relationship between the doses chosen may have no physiologic significance, and it was not shown conclusively that responses were maximal. After incubation with angiotensin, assays of the media by a method modified from that of Boucher, Biron and Genest (15) showed that pressor effect was still present, albeit at concentrations approximating 3 per cent of the initial ones.

Renin had no significant effect on synthesis of cortisol, corticosterone, or aldosterone, even when one-third of the incubation medium was replaced by fresh bovine serum.

Rat adrenal sections (Figures 4 and 5). ACTH (0.05 U per $100 \mathrm{mg}$ of tissue) and angiotensin (5 $\mu \mathrm{g}$ per $100 \mathrm{mg}$ of tissue) were added without exogenous precursor to sections of rat adrenals (Fig-

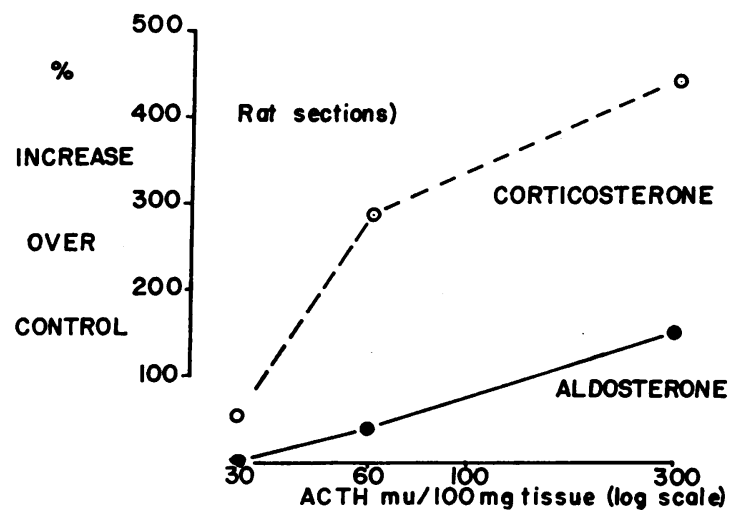

Fig. 5. EFFect of INCREASING CONCENTRATIONS OF ACTH WITHOUT ADDED PRECURSORS ON THE PRODUCTION OF ALDOSTERONE AND CORTICOSTERONE BY RAT ADRENAL SECTIONS. Each point represents the mean value of steroid production in 4 separate vessels. Comparison is made to the level of steroid synthesis in 4 control vessels with each dose of ACTH.

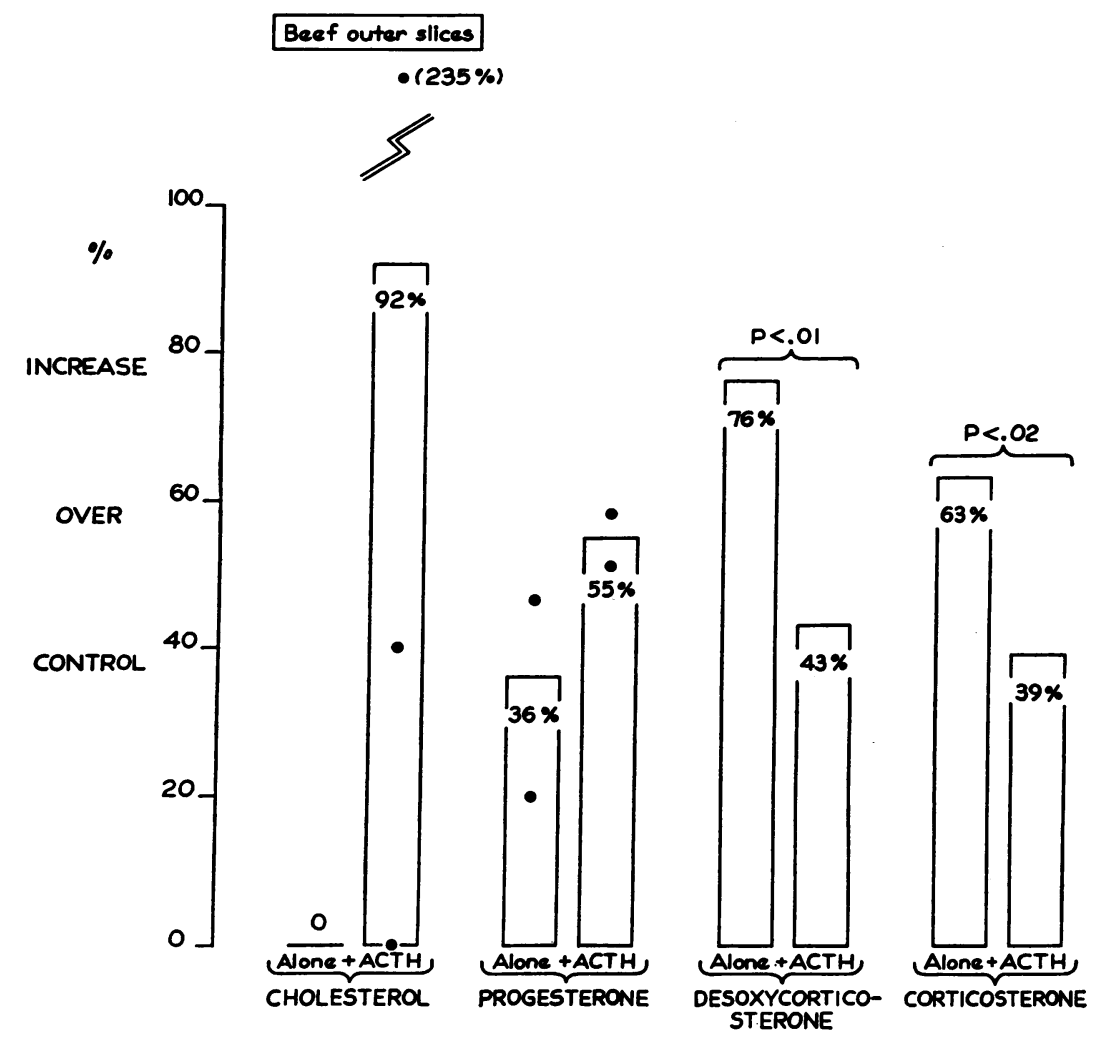

Fig. 6. EFfect of ACTH on the PRoduction of ALdosterone by OUTER SLices OF BEEF ADRENAL CORTEX IN THE PRESENCE OF STEROID PRECURSORS. Each point represents a separate experiment and each bar the average of all experiments. At least 4 vessels were included with each portion of each experiment. 
TABLE II

Effect of various precursors alone and with ACTH or angiotensin II upon aldosterone synthesis by beef adrenal slices

\begin{tabular}{|c|c|c|c|c|c|c|c|c|c|c|c|c|c|}
\hline \multirow{2}{*}{$\begin{array}{c}\text { Expt. } \\
\text { no. }\end{array}$} & \multirow[b]{2}{*}{ Precursor } & \multicolumn{3}{|c|}{ Control } & \multicolumn{3}{|c|}{ Precursor } & \multicolumn{3}{|c|}{ Precursor +ACTH } & \multicolumn{3}{|c|}{ Precursor +angiotensin } \\
\hline & & No. & Mean & SD & No. & Mean & SD & No. & Mean & SD & No. & Mean & SD \\
\hline & & \multicolumn{4}{|c|}{$\mu g / g$ tissue $/ h r$} & \multicolumn{2}{|c|}{$\mu g / g$ tissue $/ h r$} & \multicolumn{3}{|c|}{$\mu g / g$ tissue $/ h r$} & \multicolumn{3}{|c|}{$\mu g / g$ tissue $/ h r$} \\
\hline 1 & Acetete & 7 & 1.63 & 0.22 & 7 & 1.48 & 0.34 & 7 & 1.41 & 0.29 & & & \\
\hline 2 & Mevalonate & 4 & 0.94 & 0.28 & 4 & 0.89 & 0.21 & 4 & 1.01 & 0.31 & & & \\
\hline 3 & Cholesterol & 6 & 1.41 & 0.31 & 6 & 1.38 & 0.24 & 7 & 4.63 & 0.86 & 6 & 1.98 & 0.19 \\
\hline 4 & Cholesterol & 5 & 0.77 & 0.20 & 4 & 0.69 & 0.33 & 5 & 1.07 & 0.16 & 5 & 1.00 & 0.18 \\
\hline 5 & Cholesterol & 5 & 1.50 & 0.32 & 4 & 1.42 & 0.25 & 6 & 1.43 & 0.40 & 6 & 1.89 & 0.24 \\
\hline 6 & Progesterone & 4 & 0.89 & 0.25 & 5 & 1.35 & 0.22 & 5 & 1.62 & 0.77 & & & \\
\hline 7 & Progesterone & 5 & 0.77 & 0.19 & 5 & 0.93 & 0.12 & 5 & 1.10 & 0.30 & 5 & 1.00 & 0.18 \\
\hline 8 & DOC & 6 & 1.41 & 0.19 & 6 & 2.49 & 0.22 & 6 & 2.03 & 0.24 & & & \\
\hline 9 & Corticosterone & 6 & 1.39 & 0.23 & 6 & 2.36 & 0.23 & 6 & 1.96 & 0.26 & 6 & 2.30 & 0.38 \\
\hline 10 & Corticosterone & 5 & 1.86 & 0.29 & 5 & 3.04 & 0.31 & 6 & 2.58 & 0.19 & 6 & 2.97 & 0.42 \\
\hline
\end{tabular}

ure 4). At these doses ACTH had a greater effect upon the production of aldosterone and corticosterone than did angiotensin. Synthesis of corticosterone increased in each experiment, whereas synthesis of aldosterone was not increased by either stimulant when control values were above $1.5 \mu \mathrm{g}$ per $100 \mathrm{mg}$ tissue per hour. The effect of angiotensin on corticosterone and aldosterone synthesis was not significant $(p>$ 0.1 ).

The effect of increasing doses of ACTH on the production of corticosterone and aldosterone is shown in Figure 5. The effect on synthesis of corticosterone is greater at each dose level, but aldosterone production is significantly increased $(\mathrm{p}<0.02)$ with the largest dose of ACTH.

Effect of ACTH and angiotensin in the presence of precursors

Beef outer slices (Figures 6 and 7 and Table II). ACTH (1 U per $\mathrm{g}$ tissue) and angiotensin ( 0.5 and $5.0 \mu \mathrm{g}$ per $\mathrm{g}$ tissue) were added to beef outer ("glomerulosa") slices in the presence of cholesterol, progesterone, and corticosterone; with $\mathrm{ACTH}$ the experiments were done in the presence of acetate, mevalonate, and DOC as well. No

Beef outer slices

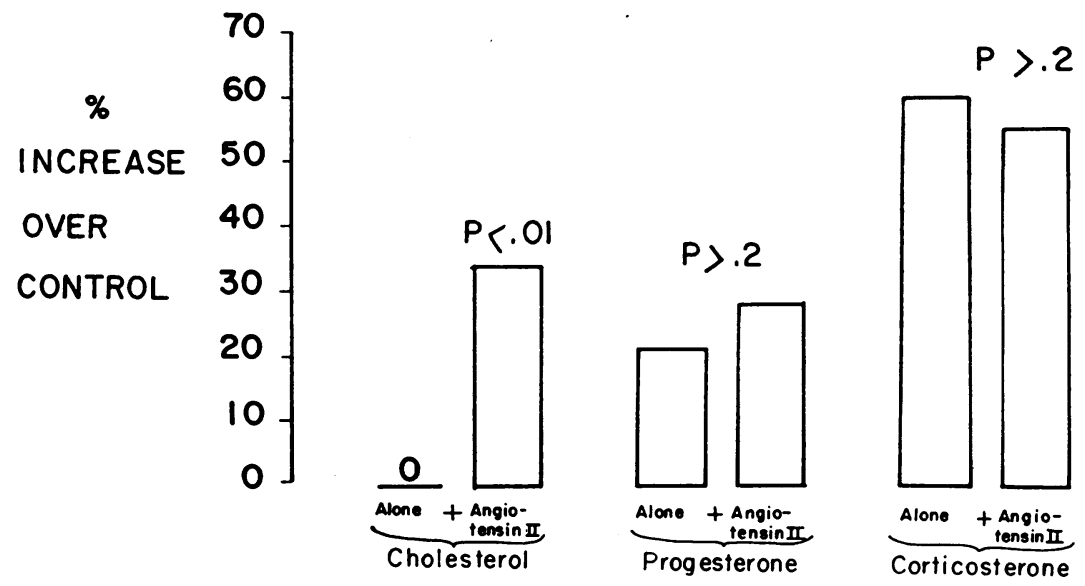

Fig. 7. EfFect of ANGiotensin II ON THE PRoduction of ALDOSTERONe by OUTER SLICES OF BEEF ADRENAL CORTEX IN THE PRESENCE OF STEROID PRECURSORS. The values for cholesterol represent the average of 3 separate experiments. At least 4 vessels were included with each portion of each experiment. 
significant increase in steroid synthesis occurred from the addition of ACTH or angiotensin alone at these dose levels. All steroids were added at a concentration of $20 \mu \mathrm{g}$ per $\mathrm{g}$ of tissue $\left(10^{-5} \mathrm{M}\right)$. ACTH increased the synthesis of aldosterone with cholesterol, but not with the other precursors (Figure 6 and Table II). This effect was striking in only one of three experiments. A similar problem in reproducibility has been noted by others in studies on corticoid synthesis with ACTH in beef slices (16). The effect of ACTH with progesterone was not statistically significant. ACTH significantly decreased aldosterone synthesis in the presence of DOC or corticosterone.

Angiotensin, at dosages of both 0.5 and $5.0 \mu \mathrm{g}$ per $g$ of tissue, also significantly increased aldosterone synthesis only from cholesterol (Figure 7). The degree of stimulation was less striking than with ACTH, but more reproducible. Angiotensin had no effect on the synthesis of aldosterone in the presence of progesterone and corticosterone.

\section{DISCUSSION}

Figure 8 shows in abbreviated form biosynthetic pathways by which aldosterone and cortisol have been shown to be formed from acetate $(17,18)$. A number of alternate pathways have been suggested. In particular, it has been claimed that the following precursors may be incorporated into adrenal steroids without traversing these pathways in their entirety: acetate (19), mevalonate (20), desmosterol (21), cholesterol (20), progesterone (22), and deoxycorticosterone (23). Evidence for these alternate pathways has been derived from measurements of the specific activity of the final product after the addition of radioactive precursors. As noted by Reiner (24), and by Zilversmit, Entenman and Fishler (25), however, the presence of radioactivity in a product shows only that some of it came from a radioactive precursor. The route by which the product was formed could be deduced only if it were possible to identify all the intermediate products and measure their pool size and rate of production as well as the total rate of production of the final product. Such measurements are not as yet available for adrenal steroids, and accordingly, the existence of alternate pathways has not been established.

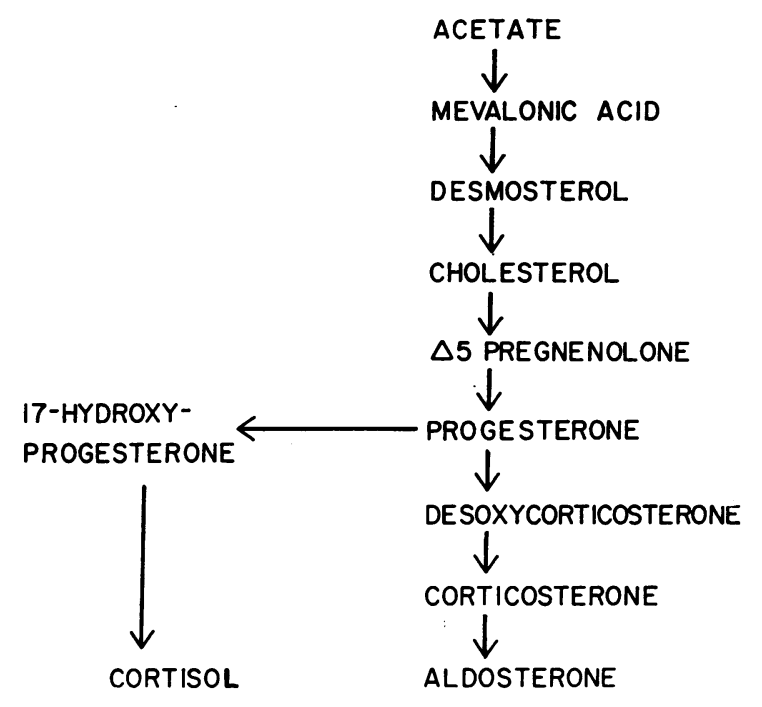

Fig. 8. Biosynthetic PATHWAYS FOR ALDOSTERone AND CORTISOL.

The increasing production of aldosterone upon addition of precursors progressively "lower" in the biosynthetic pathway, as described above, is in accord with the view that the pathways shown in Figure 8 are the important or, indeed, the only ones.

The results establish that ACTH stimulates secretion of aldosterone in vitro. Whereas an effect of ACTH on aldosterone synthesis in vivo is well established (26-28), equivocal results have heretofore been obtained in vitro $(29,30)$. Sensitive methods for analysis of aldosterone were not available when these earlier studies were done.

The results show that angiotensin, like ACTH, can directly stimulate the beef adrenal cortex to secrete aldosterone, corticosterone and cortisol. If the pathways for biogenesis of steroids are as shown in Figure 8, angiotensin, to stimulate corticosterone and cortisol production, must act at a site at least as early as progesterone.

The establishment of a direct effect of ACTH and angiotensin on the synthesis of aldosterone by beef adrenal slices makes it clear that both these agents may act without the mediation of any extra-adrenal receptors. The failure of a renin preparation to induce steroidogenesis in vitro even in the presence of beef serum, despite its clear activity in vivo (3), suggests that renin acts on steroid production only via its ability to release angiotensin (6). The amount of beef serum used 
in incubation was presumably insufficient to supply significant amounts of angiotensin II.

When ACTH was added to beef adrenal slices in the presence of precursors, synthesis of aldosterone was increased to a figure above that found with precursor alone only in the case of cholesterol. With the added cholesterol, small doses of ACTH ( $1 \mathrm{U}$ per $\mathrm{g}$ tissue), which had no effect by themselves, stimulated steroid production as much as did the larger dose ( $8 \mathrm{U}$ per $\mathrm{g}$ tissue) without cholesterol. In the case of progesterone, $\mathrm{ACTH}$ did not have a significantly greater effect than that of progesterone alone, whereas with DOC and corticosterone, ACTH induced a significant decrease in production of aldosterone. The failure of ACTH to act with precursors beyond cholesterol may indicate only that biogenesis was maximal for these slices with precursor alone. The inhibition of synthesis of aldosterone by $\mathrm{ACTH}$ in the case of DOC and corticosterone suggests that the availability of some precursor or needed cofactor has been diminished by ACTH, as, for example, by diversion towards synthesis of cortisol.

The exact site and mode of action of ACTH have not been established. Four hypotheses have been advanced. 1) Stone and Hechter (19) proposed a specific increase in the conversion of cholesterol to $\Delta^{5}$-pregnenolone. The conclusion was based on the observation that $\mathrm{ACTH}$ increased steroidogenesis when adrenal glands were perfused with cholesterol, but not when they were perfused with progesterone. This observation, like our own, places the site of action between these two precursors, but does not identify it further. 2) Haynes, Sutherland and Rall (31) proposed a specific increase in TPNH for steroid hydroxylation, produced by oxidation of 6-phosphogluconate, released in turn by phosphorylase activated by adenosine $3^{\prime}, 5^{\prime}$-phosphate ( $3^{\prime} 5^{\prime}$-AMP). TPNH is, indeed, required for cleavage of the side chain from cholesterol (32); an action of ACTH at this site would explain much of the available evidence. This cannot be the sole mode of action of ACTH, however, since ACTH may increase steroid synthesis even under conditions of maximal stimulation by TPNH or $3^{\prime} 5^{\prime}$-AMP (33), and since 3'5'-AMP and TPNH do and ACTH does not overcome inhibition of $11 \beta$ hydroxylation by methopyrapone (SU-4885) (34). 3) Hayano, Saba,
Dorfman and Hechter proposed an increase in the permeability of adrenal cortical cells to cholesterol (35), but abandoned this hypothesis in view of their own observation that ACTH can act in the absence of exogenous cholesterol. 4) Hayano and co-workers proposed an increase in the permeability of the mitochondria to cholesterol.

There is much to support the last hypothesis. The enzymes needed to cleave the side chain from cholesterol are almost exclusively localized within the mitochondria (36), so that cholesterol utilized in the synthesis of steroids must probably first enter the mitochondria. The utilization of cholesterol in steroid biosynthesis is increased in preparations with disrupted mitochondria (18), wherein contact between substrate and enzyme is presumably enhanced. ACTH is active only in whole cell preparations (37). Thus, disruption of the mitochondria produces an "ACTH-like" effect, and ACTH itself has no further action. ACTH does indeed increase the entry of cholesterol into adrenal cells (38), but attempts to demonstrate a selective increase of cholesterol in the mitochondria have been unsuccessful (39).

Our own findings are consistent with a site of action of ACTH at the level of cholesterol, but do not define further its mode of action. The effects of angiotensin upon steroidogenesis closely resemble those of ACTH. As with ACTH, cholesterol was the only precursor whose effect on biogenesis of aldosterone was further stimulated by angiotensin. The data suggest a site of action for angiotensin at or near that of $\mathrm{ACTH}$. If the action of $\mathrm{ACTH}$ on steroidogenesis does require the $3^{\prime}, 5^{\prime}$-AMP-phosphorylase-TPNH system, as discussed above, then it is likely that the role of angiotensin differs from that of ACTH. Williams (40), using the method of Rall and Sutherland (41), found that, whereas ACTH induced a twofold increase of phosphorylase activity in a preparation of beef outer slices, angiotensin had no effect on phosphorylase activity in the same preparation.

Whereas these results demonstrate that angiotensin can directly stimulate secretion of aldosterone, they do not bear upon the question as to whether stimulation of aldosterone secretion by angiotensin has a physiologic role, as, for example, in the response to sodium deprivation, as suggested by Tobian (42). Indeed, since sodium depriva- 
tion does not lead to an increased excretion of 17 hydroxycorticoids (27), our finding that cortisol secretion was consistently stimulated by angiotensin argues somewhat against such a role.

\section{SUMMARY AND CONCLUSIONS}

The effects of various precursors on biogenesis of aldosterone were studied with slices of beef adrenal cortex, and with sections of rat adrenal.

Acetate, mevalonate, and cholesterol were without effect, whereas progesterone, deoxycorticosterone, and corticosterone induced significant increases in aldosterone synthesis.

ACTH and angiotensin II stimulated synthesis of aldosterone, corticosterone, and cortisol by beef slices, whereas only ACTH had a significant effect upon aldosterone and corticosterone synthesis by rat sections.

ACTH stimulated aldosterone secretion with exogenous cholesterol, had no effect with exogenous progesterone, and significantly diminished secretion with exogenous deoxycorticosterone and corticosterone.

Angiotensin II stimulated aldosterone secretion with exogenous cholesterol but had no effect with exogenous progesterone or corticosterone.

The data are consistent with the view that ACTH and angiotensin can influence steroidogenesis at the level of cholesterol. These results do not establish a physiologic role for angiotensin.

\section{REFERENCES}

1. Genest, J., Koiw, E., Nowaczynski, W., and Sandor, T. Study of a large steroid spectrum in normal subjects and hypertensive patients. Acta endocr. (Kbh.) 1960, 35, 413.

2. Laragh, J. H., Angers, M., Kelly, W. G., and Lieberman, S. Hypotensive agents and pressor substances. The effect of epinephrine, norepinephrine, angiotensin II, and others on the secretory rate of aldosterone in man. J. Amer. med. Ass. 1960, 174, 234.

3. Bartter, F. C., Casper, A. G. T., Delea, C. S., and Slater, J. D. H. Symposium: Adrenal Steroids. On the role of the kidney in control of adrenal steroid production. Metabolism 1961, 10, 1006.

4. Mulrow, P. J., and Ganong, W. F. Stimulation of aldosterone secretion by angiotensin II. A preliminary report. Yale J. Biol. Med. 1961, 33, 386.

5. Carpenter, C. C. J., Davis, J. O., and Ayers, C. R. Relation of renin, angiotensin II, and experimental renal hypertension to aldosterone secretion. J. clin. Invest. 1961, 40, 2026.
6. Braun-Menendez, E., and Page, I. H. Suggested revision of nomenclature-Angiotensin. Science 1958, 127, 242.

7. Gomori, P., Glaz, E., Suhanyeczky, A., and Csapo, G. Aldosterone and hydrocortisone secretion in dehydration. Lancet 1960, 1, 259.

8. Eisenstein, A. B., and Hartroft, P. M. Alterations in rat adrenal cortex induced by sodium deficiency: Steroid hormone secretion. Endocrinology 1957, 60, 634.

9. Macchi, I. A., and Hechter, O. Studies of ACTH action upon perfused bovine adrenals: Corticosteroid biosynthesis in isolated glands maximally stimulated with ACTH. Endocrinology 1954, 55, 387.

10. Saffran, M., and Schally, A. V. In vitro bioassay of corticotropin: Modification and statistical treatment. Endocrinology 1955 56, 523.

11. Garren, L. D., Conney, A. H., and Tomkins, G. M. Stimulatory effect of phenobarbital on steroid metabolism (abstract). J. clin. Invest. 1961, 40, 1041.

12. Haas, E., and Goldblatt, $H$. Renin content of kidneys in experimental renal and human essential hypertension. Amer. J. Physiol. 1959, 197, 1103.

13. Kliman, B., and Peterson, R. E. Double isotope derivative assay of aldosterone in biological extracts. J. biol. Chem. 1960, 235, 1639.

14. Snedecor, G. W. Statistical Methods Applied to Experiments in Agriculture and Biology, 5th ed. Ames, Iowa, Collegiate Press, 1956.

15. Boucher, R., Biron, P., and Genest, J. Procedure for isolation and determination of human blood angiotensin. Canad. J. Biochem. 1961, 39, 581.

16. Haynes, R., Savard, K., and Dorfman, R. I. The action of adrenocorticotropic hormone on beef adrenal slices. J. biol. Chem. 1954, 207, 925.

17. Hechter, O., and Pincus, G. Genesis of the adrenocortical secretion. Physiol. Rev. 1954, 34, 459.

18. Ayres, P. J., Eichhorn, J., Hechter, O., Saba, N., Tait, J. F., and Tait, S. A. S. Some studies on the biosynthesis of aldosterone and other adrenal steroids. Acta endocr. (Kbh.) 1960, 33, 27.

19. Stone, D., and Hechter, O. Studies on ACTH action in perfused bovine adrenals: The site of action of ACTH in corticosteroidogenesis. Arch. Biochem. 1954, 51, 457.

20. Barlow, J. J., Holub, D. A., and Jailer, J. W. Pathways of aldosterone biosynthesis. Clin. Res. 1960, 8, 373.

21. Melby, J. C., St. Cyr, M., and Dale, S. L. Alterations in steroid hormone secretion produced by inhibition of cholesterol biosynthesis (abstract). J. clin. Invest. 1961, 40, 1063.

22. Travis, R. H., and Farrell, G. L. In vitro biosynthesis of isotopic aldosterone: Comparison of precursors. Endocrinology 1958, 63, 882.

23. Kahnt, F. W., Neher, R., and Wettstein, A. Bildung von 18-und 19-Oxy-cortexon durch Einwirkung 
von Nebennieren-Homogenaten auf Cortexon. Helv. chim. Acta 1955, 38, 1237.

24. Reiner, J. M. The study of metabolic turnover rates by means of isotopic tracers. I. Fundamental relations. Arch. Biochem. 1953, 46, 53.

25. Zilversmit, D. B., Entenman, C., and Fishler, M. C. On the calculation of "turnover time" and "turnover rate" from experiments involving the use of labeling agents. J. gen. Physiol. 1943, 26, 325.

26. Singer, B., and Stack-Dunne, M. P. The secretion of aldosterone and corticosterone by the rat adrenal. J. Endocr. 1955, 12, 130.

27. Liddle, G. W., Duncan, L. E., Jr., and Bartter, F. C. Dual mechanism regulating adrenocortical function in man. Amer. J. Med. 1956, 21, 380.

28. Farrell, G. L., Rauschkolb, E. W., and Koletsky, S. Secretion of aldosterone by hypophysectomized dogs (abstract). J. clin. Endocr. 1955, 15, 852.

29. Rosenfeld, G., Rosemberg, E., Ungar, F., and Dorfman, R. I. Regulation of the secretion of aldosterone-like material. Endocrinology 1956, 58, 255.

30. Stachenko, J., and Giroud, C. J. P. Functional zonation of the adrenal cortex: Site of ACTH action. Endocrinology 1959, 64, 743.

31. Haynes, R. C., Jr., Sutherland, E. W., and Rall, T. W. The role of cyclic adenylic acid in hormone action. Recent Progr. Hormone Res. 1960, $16,121$.

32. Halkerston, I. D. K., Eichhorn, J., and Hechter, O. A requirement for reduced triphosphopyridine nucleotide for cholesterol side-chain cleavage by mitochondrial fractions of bovine adrenal cortex. J. biol. Chem. 1961, 236, 374.
33. Peron, F. G. Further studies on the mode of action of the adrenocorticotropic hormone. J. biol. Chem. 1961, 236, 1764.

34. Barlow, J. J., and Holub, D. A. Adrenal inhibitors and stimulators in Program of the Forty-third Meeting of the Endocrine Society, June 22, 1961, p. 18.

35. Hayano, M., Saba, N., Dorfman, R. I., and Hechter, $O$. Some aspects of the biogenesis of adrenal steroid hormones. Recent Progr. Hormone Res. 1956, $12,79$.

36. Saba, N., and Hechter, O. Cholesterol-4-C $C^{14}$ metabolism in adrenal homogenates. Fed. Proc. 1955, 14, 775.

37. Macchi, I. A., and Hechter, O. Lack of influence of ACTH upon corticosteroid biosynthesis in cow adrenal homogenates. Arch. Biochem. 1954, 53, 305.

38. Dougherty, T. F., and Berliner, D. L. Some ways by which ACTH and cortisol influence functions of connective tissue in Connective Tissue, Thrombosis, and Atherosclerosis, I. H. Page, Ed. New York, Academic Press, 1959, p. 143.

39. Hechter, O. Concerning possible mechanisms of hormone action. Vitam. and Horm. 1955, 13, 293.

40. Williams, H. E. Unpublished observations.

41. Rall, T. W., and Sutherland, E. W. Formation of a cyclic adenine ribonucleotide by tissue particles. J. biol. Chem. 1958, 232, 1065.

42. Tobian, L. Interrelationship of electrolytes, juxtaglomerular cells and hypertension. Physiol. Rev. 1960, 40, 280. 